DOI: 10.17707/AgricultForest.63.1.13

\begin{abstract}
Valentine BRAILKO, Olga MITROFANOVA, Nina LESNIKOVASEDOSHENKO, Svetlana CHELOMBIT, Irina MITROFANOVA ${ }^{I}$
\end{abstract}

\title{
ANATOMY FEATURES OF LAVANDULA ANGUSTIFOLIA MILL. AND LAVANDULA HYBRIDA REV. PLANTS IN VITRO
}

\section{SUMMARY}

Lavender and lavandin are widely used in food, pharmaceutical, cosmetic industries and ornamental gardening. Gene pool collection of Lavandula angustifolia and lavandin is presented in Nikita Botanical Gardens plots and the same collection is being created in vitro.

Initial explants of L. angustifolia, its cultivars 'Belyanka', 'Record' and L. hybrida - 'Rabat' and 'Snezhnyi Bars' were introduced in vitro. Plant regeneration occurred on MS medium supplemented with 0.3-0.5 $\mathrm{mg}^{-1}$ kinetin, $0.025 \mathrm{mg} \mathrm{l}^{-1} \mathrm{NAA}, 0.25 \mathrm{mg} \mathrm{l}^{-1} \mathrm{GA}_{3}$. Samples were analyzed after 2 and 8 months of culture.

Structural analysis of regenerated plants vegetative organs enabled assessment of their morphogenetic capacity. Under in vitro culture 2-5 microshoots/explants were produced with the height of $2.3-8.2 \mathrm{~cm}$. Leaves were opposite, sessile linear or linear-lanceolate, with entire edges curved outward, densely pubescent, and 10-30 leaves/microshoot. Leaf lamina length was 0.9$1.5 \mathrm{~cm}$. Leaves were bifacial, amphystomatic, lamina thickness $-132-215 \mu \mathrm{m}$, palisade rate was 0.38-0.41 after 2 months culture and 0.56-0.58 - after 8 months. Epidermal thickness was 8-19 $\mu \mathrm{m}$, cells were relatively small with thin, cellulose walls covered with cuticle. Stomata are of anomocyte type, small, raised above the epiderm cells, $48-150 \mathrm{pcs} / \mathrm{mm}^{2}$ on adaxial surface, $115-432$ $\mathrm{pcs} / \mathrm{mm}^{2}-$ on abaxial one. Essential oils are produced in simple and glandular, unicellular and multicellular hairs of epidermal origin, located above the leaf chlorophyll tissue. Features of xeromorphic structure appeared at a long-term in vitro cultivation. structure.

Keywords: lavender, lavandin, regenerant, leaf anatomy, xeromorphic

\section{INTRODUCTION}

In Eastern Europe, over 60 species of medicinal plants are cultivated. Lavandula angustifolia is among the three leading medicinal and aromatic crops. Lavender breeding in Nikita Botanical Gardens engaged since 1926. Cultivars

\footnotetext{
${ }^{1}$ Valentine Brailko (corresponding author: brailko@yandex.ua), Olga Mitrofanova, Nina Lesnikova-Sedoshenko, Svetlana Chelombit, Irina Mitrofanova Nikita Botanical Gardens National Scientific Centre, Nikita, Yalta, 298648, RUSSIA

Paper presented at the $7^{\text {th }}$ International Scientific Agricultural Symposium "AGROSYM 2016".

Notes: The authors declare that they have no conflicts of interest. Authorship Form signed online.
} 
with high oil yield, great part of esters, excellent fragrance evaluation, different terms of blossom, winter-hard and suitable for mechanized cultivation have been created (Mitrofanov et al., 2005).

As it is known, lavender could be successfully propagated both by seeds and vegetatively - by cuttings, layering and shrub dividing. Despite the fact that seed propagation method is the simplest and economically costly, it is not widely used as it is resulted in the offspring splitting (Rabotyagov et al., 2014). In this regard, the more efficient way is vegetative propagation. However, the problem of viral pathogens damages in collection plots and industrial plantings hinders vegetative propagation, and as a result, reduces possibility of promising lavender cultivars large-scale cultivation. Nowadays, producing of high-quality virus-free planting material identical to the parent plants is provided with biotechnological methods of plant cleaning up and micropropagation (Milošević et al., 2012; Bhojwani \& Dantu, 2013; Mitrofanova et al., 2014.).

Present study included cultivars of interspecific lavender hybrids ( $L$. angustifolia Mill $\times$ L. latifolia Medie.) - Lavandin (L. hybrida Rev.) that are characterized by biological and economically valuable features exceeded the original species.

Some researchers (Sudria et al., 1999; Toma et al., 2004, Nikolakaki and Christodoulakis, 2006) indicated the possibility of essential oil obtaining from vegetative mass of Labiatae species and cultivars under in vitro conditions. Herewith, great attention was turned to the processes of histogenesis and organogenesis in cultured cultivars.

In this regard, the aim of our research was to study regeneration features in lavender and Lavandula plants, to evaluate morphological and anatomical parameters of tissues in various cultivars under in vitro conditions, to reveal those features variability according to the genotype, and thus, to determine morphogenetic capacity of regenerants.

\section{MATERIALS AND METHODS}

For study as a plant material microshoots of valuable lavender (Belyanka, Record) and Lavandin (Rabat, Snezhnyi Bars) cultivars from the collection of the Nikita Botanical Gardens, cultured in vitro were used.

From field grown intact plants the apical meristems of axillary buds were introduced in aseptic culture. Virus-free microshoots were cultured on modified MS medium with $0.3 \mathrm{mg} \mathrm{l}^{-1}$ Kinetin, $0.025 \mathrm{mg} \mathrm{l}^{-1} \mathrm{NAA}$ and $0.25 \mathrm{mg}^{-1} \mathrm{GA}_{3}$. Explants in the culture vessels were kept in a growth chamber at $25 \pm 1^{\circ} \mathrm{C}$ under 16-h photoperiod supplied by cool-white fluorescent lamps giving $37.5 \mu \mathrm{mol} \mathrm{m}$ $\mathrm{s}^{-1}$. Investigation material was collected after 2 and 8 months of culture.

For the analysis we took the third pair of leaves at microshoot apex from 10 microshoots in each treatment. Anatomic slides were prepared by common methods (Pausheva, 1990). Histological and anatomical studies of leaves in regenerants was carried out under a light microscope AxioScope A.1 (Zeiss, 
Germany) using software Axio Vision Rel applications. 4.8.2. Essential oil presence in leaf tissues was set by Sudan III staining.

\section{RESULTS AND DISCUSSION}

During the study, morphological differences between the studied cultivars were already noticed at the initial stages of culture (Fig. 1). They appeared both in leaf color of microshoots: light-green narrow-linear or lanceolate in the cultivars Belyanka and Record and dark green in the cultivars Rabat and Snezhnyi Bars, and some quantitative parameters: number of microshoots produced per explant, microshoot height, size and number of leaves (Table 1).

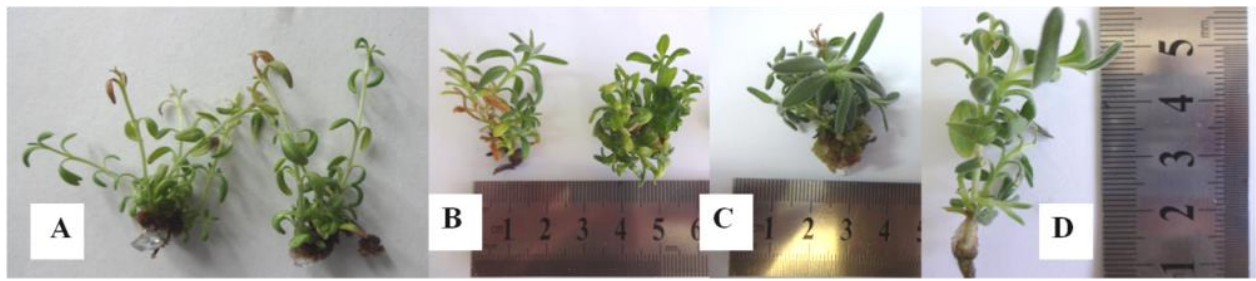

Figure 1. Regenerants appearance in lavender cultivars: A - Belyanka, B - Record and Lavandin cultivars: C - Rabat, D - Snezhnyi Bars after 2 months culture.

Table 1. Quantitative characteristics of regenerant morphological structures in lavender and lavandin $(\mathrm{M} \pm \mathrm{SE})$

\begin{tabular}{|c|c|c|c|c|c|c|}
\hline \multicolumn{3}{|c|}{ Cultivar, time of culture } & \multirow{2}{*}{$\begin{array}{c}\begin{array}{c}\text { Microshoot } \\
\text { number per } \\
\text { explants, pes }\end{array} \\
3.4 \pm 1.3\end{array}$} & \multirow{2}{*}{$\begin{array}{c}\begin{array}{c}\text { Microshoot } \\
\text { height }(\mathbf{c m})\end{array} \\
5.8 \pm 1.5\end{array}$} & \multirow{2}{*}{\begin{tabular}{|c|}
$\begin{array}{c}\text { Number of } \\
\text { leaves } \\
\text { (pcs) }\end{array}$ \\
$22.8 \pm 9.2$
\end{tabular}} & \multirow{2}{*}{$\begin{array}{c}\begin{array}{c}\text { Leaf size, } \\
\text { cm }\end{array} \\
1.2 \times 0.3\end{array}$} \\
\hline \multirow{4}{*}{$\begin{array}{l}\bar{\theta} \\
\overline{0} \\
\stackrel{0}{0}\end{array}$} & \multirow[t]{2}{*}{ Belyanka } & $1 *$ & & & & \\
\hline & & 2 & $3.2 \pm 1.5$ & $3.5 \pm 0.8$ & $14.8 \pm 8.6$ & $1.2 \times 0.2$ \\
\hline & \multirow{2}{*}{ Record } & 1 & $3.2 \pm 1.6$ & $2.5 \pm 0.4$ & $12.5 \pm 5.0$ & $1.0 \times 0.2$ \\
\hline & & 2 & $2.8 \pm 1.2$ & $4.1 \pm 1.2$ & $19.4 \pm 6.5$ & $1.1 \times 0.2$ \\
\hline \multirow{4}{*}{ 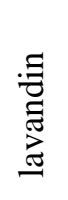 } & \multirow{2}{*}{ Rabat } & 1 & $1.7 \pm 0.5$ & $2.3 \pm$ & $8.0 \pm 4.6$ & $1.4 \times 0.4$ \\
\hline & & $\frac{1}{2}$ & $3.1 \pm 1.6$ & & $14.0 \pm 5.0$ & \\
\hline & \multirow{2}{*}{$\begin{array}{c}\text { Snezhnyi } \\
\text { Bars }\end{array}$} & 1 & $1.2 \pm 0.8$ & $4.9 \pm 1.1$ & $13.3 \pm 8.4$ & $1.6 \times 0.4$ \\
\hline & & 2 & $2.0 \pm 1.0$ & $4.5 \pm 0.8$ & $18.4 \pm 4.5$ & $1.4 \times 0.3$ \\
\hline
\end{tabular}

$1^{*}$ - the first passage, 2 months culture; 2 - the fourth passage, 8 months culture.

Greater number of microshoots (5 pcs) with maximum small leaves per shoot formed Belyanka cultivar. In Lavandin cultivars 1-2 microshoots with a denser leaf arrangement in the cultivar Rabat and extended internodes in the cultivar Snezhnyi Bars formed. Leaves in Lavandin cultivars were larger and less acuminate at the top than in lavender cultivars. Leaf blade length exceeded its width 4-5 times.

Those morphological features are characteristics of leaves under growing in the field (Rabotyagov, 2014). 
Under prolonged culture (4 $4^{\text {th }}$ passage) in all studied cultivars $2-4$ microshoots were noticed in the average, branching occurred at the second or third pair of leaves on microcuttings. Cultivar Rabat had the largest leaves in all investigated culture stages.

Leaf blades were bifacial (Fig. 2), differentiated mesophyll was observed from early terms of microshoot culture in vitro. Leaf thickness increased under a long term culture (Table 2). Adaxial epidermis consisted of small isodiametric (cultivars Snezhnyi Bars and Record) or slightly elongated (cultivars Rabat and Belyanka) thin-walled cellulose cells with flexuous outlines, covered with thin cuticle layer (Table 3). Leaf abaxial epidermis in all studied cultivars consisted of smaller cells.

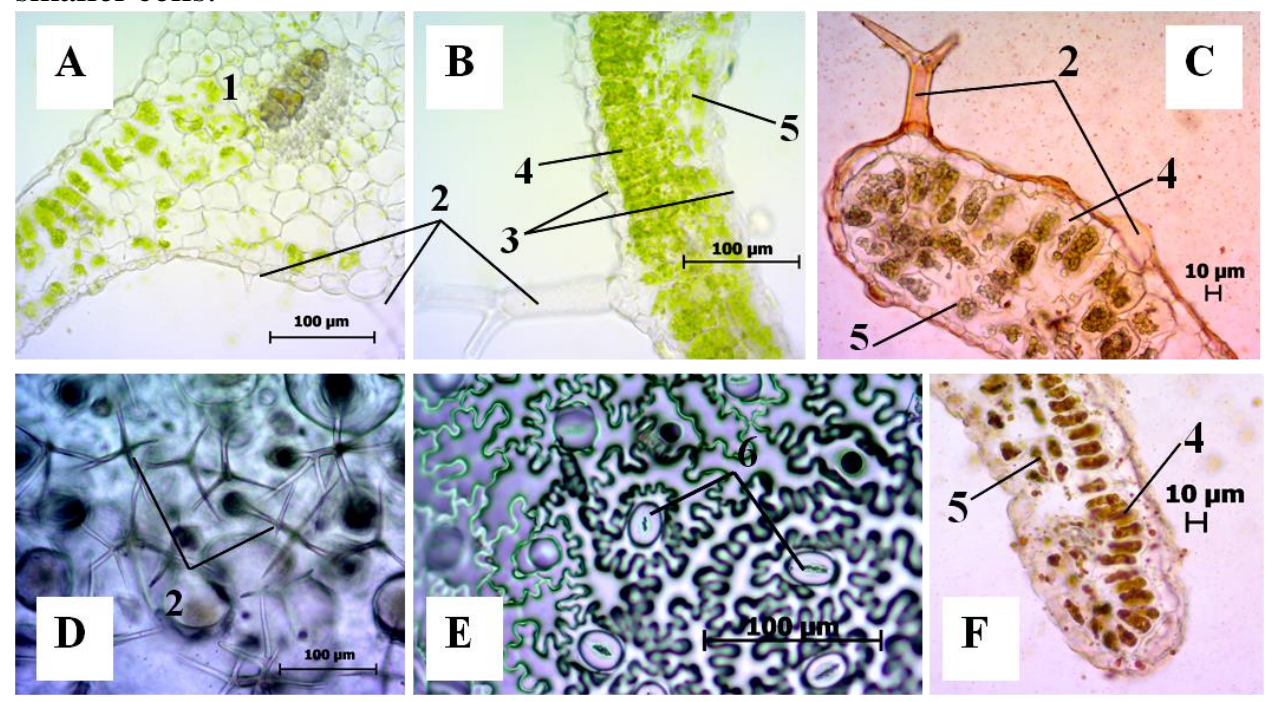

Figure 2. Leaf blade structure in lavandin cultivar Rabat in vitro: A, B - crosssection, C, F -cross sections stained with Sudan III; D, E - molds of abaxial epidermis; 1 - vascular bundle, 2 - trichomes, 3 - epidermis, 4 - palisade mesophyll, 5 - spongy mesophyll, 6 - stomatal apparatus.

Table 2. Anatomical characteristics of leaf blade transverse sections in lavender and lavandin regenerants $(\mathrm{M} \pm \mathrm{SE}, \mu \mathrm{m})$

\begin{tabular}{|c|c|c|c|c|c|c|c|c|c|}
\hline \multirow{3}{*}{\multicolumn{2}{|c|}{$\begin{array}{c}\text { Indexes of anatomical } \\
\text { structure }\end{array}$}} & \multicolumn{4}{|c|}{ Lavender } & \multicolumn{4}{|c|}{ Lavandin } \\
\hline & & \multicolumn{2}{|c|}{ Belyanka } & \multicolumn{2}{|c|}{ Record } & \multicolumn{2}{|c|}{ Rabat } & \multicolumn{2}{|c|}{ Snezhnyi Bars } \\
\hline & & $1 *$ & 2 & 1 & 2 & 1 & 2 & 1 & 2 \\
\hline \multicolumn{2}{|c|}{ Leaf blade thickness } & $\begin{array}{c}130 \pm \\
12\end{array}$ & $\begin{array}{c}169 \pm \\
16\end{array}$ & $\begin{array}{c}145 \pm \\
15\end{array}$ & $\begin{array}{c}174 \pm \\
43\end{array}$ & $\begin{array}{c}151 \pm \\
24\end{array}$ & $\begin{array}{c}190 \pm \\
26\end{array}$ & $\begin{array}{c}159 \pm \\
13\end{array}$ & $\begin{array}{c}168 \pm \\
21\end{array}$ \\
\hline $\begin{array}{l}\text { Epidermis } \\
\text { thickness }\end{array}$ & & $\begin{array}{l}9 \pm 3 \\
5 \pm 2\end{array}$ & $\begin{array}{c}14 \pm 5 \\
9 \pm 3\end{array}$ & $\begin{array}{l}9 \pm 2 \\
6 \pm 2\end{array}$ & $\begin{array}{c}15 \pm 3 \\
8 \pm 2\end{array}$ & $\begin{array}{c}10 \pm 3 \\
8 \pm 2\end{array}$ & $\begin{array}{l}19 \pm 7 \\
11 \pm 5\end{array}$ & $\begin{array}{c}10 \pm 4 \\
6 \pm 2\end{array}$ & $\begin{array}{c}14 \pm 2 \\
9 \pm 4\end{array}$ \\
\hline $\begin{array}{l}\text { Mesophyll } \\
\text { thickness }\end{array}$ & & $\begin{array}{l}45 \pm 13 \\
71 \pm 16\end{array}$ & $\begin{array}{l}80 \pm 12 \\
61 \pm 15\end{array}$ & $\begin{array}{c}49 \pm 7 \\
81 \pm 15\end{array}$ & $\begin{array}{l}85 \pm 10 \\
62 \pm 16\end{array}$ & $\begin{array}{l}55 \pm 15 \\
78 \pm 12\end{array}$ & $\begin{array}{c}90 \pm 8 \\
68 \pm 12\end{array}$ & $\begin{array}{c}58 \pm 9 \\
86 \pm 12\end{array}$ & $\begin{array}{l}82 \pm 7 \\
59 \pm 5\end{array}$ \\
\hline \multicolumn{2}{|c|}{ Palisade index } & 0.39 & 0.56 & 0.38 & 0.57 & 0.36 & 0.56 & 0.40 & 0.58 \\
\hline
\end{tabular}

$1^{*}$ - the first passage, 2 months culture; 2 - the fourth passage, 8 months culture. 
Table 3. Anatomical characteristics of leaf blade epidermis structure in lavender and Lavandula microshoots (after 8 months culture, $\mathrm{M} \pm \mathrm{SE}, \mu \mathrm{m}$ )

\begin{tabular}{|c|c|c|c|c|c|}
\hline \multirow{2}{*}{$\begin{array}{c}\text { Indexes of anatomical } \\
\text { structure/Cultivars }\end{array}$} & \multicolumn{2}{c|}{ Lavender } & \multicolumn{2}{c|}{ Lavandula } \\
\cline { 2 - 6 } & & Belyanka & Record & Rabat & Snezhnyi Bars \\
\hline \multirow{2}{*}{ Epidermis cells size } & $1 *$ & $60 \times 33$ & $32 \times 23$ & $52 \times 35$ & $29 \times 27$ \\
& 2 & $46 \times 28$ & $59 \times 33$ & $39 \times 30$ & $28 \times 22$ \\
\hline Stomata pore size & 1 & $27 \times 13$ & $17 \times 7$ & $25 \times 11$ & $25 \times 14$ \\
(length $\times$ width) & 2 & $29 \times 14$ & $31 \times 15$ & $26 \times 10$ & $17 \times 10$ \\
\hline Stomata number per & 1 & $102 \pm 16$ & $150 \pm 19$ & $127 \pm 24$ & $48 \pm 16$ \\
\cline { 2 - 6 } $1 \mathrm{~mm}^{2}$ surface & 2 & $180 \pm 21$ & $115 \pm 13$ & $432 \pm 52$ & $283 \pm 27$ \\
\hline Trichome number per & 1 & $21 \pm 8$ & $48 \pm 6$ & $38 \pm 6$ & $26 \pm 9$ \\
\cline { 2 - 6 } $1 \mathrm{~mm}^{2}$ surface & 2 & $52 \pm 6$ & $75 \pm 13$ & $72 \pm 6$ & $60 \pm 10$ \\
\hline
\end{tabular}

$1 *$ - on adaxial surface, 2 - on abaxial surface of the leaf blade

Vascular bundles in leaves are collateral. They are located in the middle layers of mesophyll (Fig. 2). Bundles of lateral veins consisted of three or four xylem and phloem vessels. Leaves were amfistomatic, under prolonged culture their significant predominance on abaxial surface was noticed. Stomata are anomocytic (ranunculaceous), and differed in sizes, raised above the base of the epidermis cells.

It is worth saying that density of stomata distribution had significant differences in the studied cultivars. Thus, in lavender cultivars it was 102-180 stomata $/ \mathrm{mm}^{2}$, stomata arranged substantially uniformly. In the cultivar Record numerous small stomata located on adaxial side, and the largest $(31 \times 15 \mu \mathrm{m})$ one in a lower number were on the abaxial side. Maximum number of stomata and their largest size were found in the cultivar Rabat. Guard cells are oval.

Our study demonstrated that pubescence of leaves' in vitro regenerated plants consist of single or double-celled simple, slightly branched trichomes and 2-4-, rarely 6-cell capitate glandular hairs. Their number is also greater on abaxial side $\left(52-75\right.$ trichomes $\left./ \mathrm{mm}^{2}\right)$. Due to leaves cross-sections analysis it was established that the part of glandular hairs was $23-38 \%$ of the total trichomes number. That corresponds to the data presented A. Nikolakaki and N.S. Christodoulakis (2006) who are reported that in Lavandula vera L. cultivars number of cells with secreting activity was not more than $30 \%$.

M. R. Zuzarte et al. (2010) during morphological analysis demonstrated that trichomes on Lavandula pedunculata leaves in vitro are similar to the ones in intact plants. Histological investigation by Avato P. (2005) and Kamatou G.P.P. (2007) over Salvia officinalis, S. albicaulis and S. dolomitica plants on different stages of aseptic culture demonstrated the presence of shield-shaped glandular scales that produced high quality essential oils. Glandular trichomes were also described on leaf surface in Mentha piperita regenerants (Santoro et al., 2013). Glandular hairs are formed from epidermal outgrowths that divide asymmetrically to produce basal cells (Turner et al., 2000). 
At the same time we are observed that the greatest accumulation of essential oil in dispersed state occurred in capitate glandular hairs. Also, essential oil droplets were formed in small amounts in the vacuoles of mesophyll cells. They were especially strongly expressed in the cells of palisade parenchyma. In lavandin cultivar Rabat drops of essential oil were more numerous and larger than in the other studied cultivars. For that cultivar their formation was also noted in the cells of parenchymal sheath of vascular bundles.

Mesophyll was multi-layered, consisting of 1-2 palisade chlorenchym rows with elongated, tightly arranged cells and 2-3 rows of spongy tissue with loose cell arrangement, contact with one another with protrusions. In all studied leaves from the microshoots of first passage palisade tissue consisted of a single layer, 45-58 $\mu \mathrm{m}$ thick. Palisade index was maximum in the cultivars Snezhnyi Bars (0.40) and Belyanka (0.39). Cells had oval-round shape. On the leaf sections from the $4^{\text {th }}$ passage 2 layers of palisade cells were often observed. Maximum development palisade chlorenchym had in Rabat cultivar $(90 \pm 8 \mu \mathrm{m})$. Palisade index increased to $0.56-0.58$.

As V.D. Rabotyagov et al. (2014) pointed out; in interspecific hybrids intermediate type of anatomical structure inheritance is expressed. This phenomenon can be explained by the increase of homeostasis, which enables them to better adapt to low and high air humidity and substrate.

\section{CONCLUSIONS}

Thus, we not found any significant difference between lavender and lavandin cultivars in development of vegetative organs, formation leaves and internodes under long-time in vitro culture. Differences in the studied cultivars identified in leaf blades shape, color and size.

Anatomical analysis of microshoot leaves demonstrated that together with mentioned morphological features of vegetative organs, there were differences in such parameters as leaf blade thickness, stomata number on abaxial surface and essential oil localization.

Chlorenchym in the studied cultivars differentiated into palisade and spongy tissue. Sophistication of palisade leaf tissue in the cultivars Rabat and Record, cutinized cover tissues, dense pubescence confirm the presence of xeromorphic features and ability to water stress adaptation under ex vitro conditions. At the same time, large cells and loose arrangement of mesophyll in the cultivars Belyanka and Snezhnyi Bars demonstrated ability to develop normally both in xeromorphic environment and in wet habitats. Essential oil was accumulated in glandular and simple hairs, as well as in vacuoles of mesophyll cells and cells of mechanical leaf tissues in dispersed state.

Knowledge of leaf anatomy in the studied cultivars under in vitro conditions could be used in lavender and lavandin breeding works.

\section{ACKNOWLEDGMENT}

This study was funded by a research grant № 14-50-00079 of the Russian Science Foundation. 


\section{REFERENCES}

Avato, P., Fortunato, I. M., Ruta, C., \& D'Elia, R. (2005). Glandular hairs and essential oils in micropropagated plants of Salvia officinalis L. Plant Science,169(1), 29-36.

Bhojwani S.S., Dantu P.K. (2013). Production of Virus-free Plants. In: Plant Tissue Culture: An Introductory Text, 227-243. doi: 10.10007 / 978-81-322-1026-9_16.

Kamatou, G. P. P., Viljoen, A. M., Figueiredo, A. C., Tilney, P. M., Van Zyl, R. L., Barroso, J. G., \& Van Vuuren, S. F. (2007). Trichomes, essential oil composition and biological activities of Salvia albicaulis Benth. and $S$. dolomitica Codd, two species from the Cape region of South Africa. South African Journal of Botany, 73(1), 102-108.

Milošević S., Cingel A., Jevermovic S., Stancovic I., Bulagic A., Krstić B., \& Subotic A. (2012). Virus elimination from ornamental plants using in vitro culture techniques. Pestic. Phytomed, 27 (3), 203-211. doi: 10.2298 / PIF1203203M.

Mitrofanov V.I., Rabotyagov V.D., Samoylov Yu.K., Azarova Z.F., \& Aksenov Yu.V. (2005). Lavender: elite nurseries, Yalta, NBG-NSC, 60 p.

Mitrofanova O.V., Mitrofanova I.V., Lesnikova-Sedoshenko N.P., \& Ivanova N.N. (2014). Using of biotechnological methods for plants improvement and propagation of virus-free planting material of perspective ornamental plants. Works of the State Nikit. Botan. Gard., 138, 5-56.

Nikolakaki A., Christodoulakis N.S. (2006). Histological investigation of the leaf and leaf-originating calli of Lavandula vera L. Israel Journal of Plant Sciences, 54 (4), 281-290, doi: 10.1560/IJPS_54_4_281.

Pausheva Z.P. (1990) Practicum in plant cytology. M., Kolos, 283 p.

Rabotyagov V.D., Svidenko L.V., \& Boyko M.F. (2014). Anatomical and morphological features of interspecific F1 hybrids in comparison with the original diploid species and tetraploid. Chornomors'k. bot.z., 10 (1), 127-137. doi: 10.14255 / 2308-9628 / $14.101 / 14$.

Santoro, M.V., Nievas, F., Zygadlo, J., Giordano, W., \& Banchio, E. (2013). Effects of growth regulators on biomass and the production of secondary metabolites in peppermint (Mentha piperita) micropropagated in vitro. American Journal of Plant Sciences, 4, 49-55. doi: 10.4236/ajps.2013.45A008.

Sudria C., Pinol M.T., Palazon J., Cusido R.M., Vila R., Morales C., Bonfill M., \& Canigueral S. (1999). Influence of plant growth regulators on the growth and essential oil content of cultured Lavandula dentate plantlets. Plant Cell Tissue Organ. Cult., 58 (3), 177-184. http://dx.doi.org/10.1023/A:1006377003962

Toma I., Toma C., Ghiorghita G. (2004). Histo-anatomy and in vitro morphogenesis in Hyssopus officinalis L. (Lamiaceae). Acta Botanica Croatica, 63 (1), 59-68.

Turner, G.W., Gershenzon, J., \& Croteau, R.B. (2000). Development of peltate glandular trichomes of peppermint. Plant Physiology, 124(2), 665-680.

Zuzarte, M.R., Dinis, A.M., Cavaleiro, C., Salgueiro, L.R., \& Canhoto, J.M. (2010). Trichomes, essential oils and in vitro propagation of Lavandula pedunculata (Lamiaceae). Industrial Crops and Products, 32(3), 580-587. 